\title{
生体インピーダンス法を用いた 内臓脂肪推定モデルの開発
}

\author{
米田 光宏*1・田㟝 博*1 $・$ 土屋 直樹*1・中嶋 宏*1・ \\ 濱口 剛宏 $* 2 \cdot$ 奥 正次郎 $* 2 \cdot$ 志賀 利一 $* 2$
}

\begin{abstract}
生体インピーダンス法を用いて内臟脂肪量を推定する手法は, X線CTP MRIによる計測に比べると, コ ストや安全性の点で優れている。しかし，この手法で高い推定精度を実現するためには，複雑な組成を持 つ生体の個体差を考慮した計測とその信号解析およびモデリングが重要となる。本稿では, 特徴量のバリ エーションを確保し，有効な特徴量の選定によるモデリング手法を提案する。具体的には，カーディナリ ティという指標を用いて特徵量の性質を定量的に評価することにより，特徴量のバリエーションを確保す る。さらに，統計的な評価指標である赤池情報量規準を用いることにより，特徴量の選定を行う。実験の 結果，提案手法によって構築した推定モデルが，高い推定精度と安定性を示すことを確認した。
\end{abstract}

キーワード：特徴選択，カーディナリティ，内臓脂肪，皮下脂肪，生体インピーダンス法

\section{1. はじめに}

先進諸国に扔いて少子高齢化がますます深刻な社会 問題と化している。このような背景の中，生活の質の 維持・向上を実現するためには, 健康寿命の伸長が社 会的に取り組むべき重要な課題といえる。特に，生活 習慣病に深く関わりのあるメタボリックシンドローム への関心は，急速に社会へ浸透している．現行の健康 診断では, ウエスト周囲長の計測に加えて, 血糖, 血 圧，および血液中の脂質の計測を行うことによって， メタボリックシンドロームの第一次的判断がなされて いる。 ウエスト周囲長は, その計測の簡便性から内臓 脂肪量を把握するための代替指標として使用されてい る [1]。しかし，この指標は皮下脂肪量や脂肪以外の 体組成の影響を受けるため, 内臓脂肪量を正確に把握 することは困難である.

一方，医療現場では，この内臟脂肪量を正確に把握 するために, X 線CT(Computerized Tomo-graphy)や MRI (Magnetic Resonance Imaging)を用いて撮影し た腹部断面画像から, 内臟脂肪の面積が計算されてい る [2][3]。これらの装置は非常に高価であり, 計測手

\footnotetext{
$\dagger$ Development of Visceral Fat Estimation Model Based on Bioelectrical Impedance Analysis Method

Mitsuhiro YONEDA, Hiroshi TASAKI, Naoki TSUCHIYA, Hiroshi NAKAJIMA, Takehiro HAMAGUCHI, Shojiro OKU and Toshikazu SHIGA

*1 オムロン株式会社 OMRON Corporation

*2 オムロンヘルスケア株式会社

OMRON HEALTHCARE Co., Ltd.
}

順も煩雑であるという課題がある。X線CTの場合は被 曝の問題もある。このような問題を持つ現行の内臟脂 肪計測手法に対して, 簡便かつ安全で, 正確な内臓脂 肪量の計測手法が望まれている。

この課題に対する有望な手法として, 生体インピー ダンス法を用いた内臓脂肪量の推定手法が提案されて いる. 生体インピーダンス法とは, 生体に微弱な電流 を通電した際に計測される電気抵抗から，脂肪などの 体組成に関する情報を推定する手法である，本手法は 計測の簡便性および安全性から, 体脂肪計測器などの 一般家庭用の健康管理機器に応用されている。本稿で は, 生体インピーダンス法を利用した内臓脂肪面積推 定モデルを獲得する手法について議論を行う。

以降，2節では関連研究に関して，3 節では生体イ ンピーダンス法の計測原理と提案する推定モデルの獲 得手法について述べる。そして，4節では提案手法に よって獲得された推定モデルの推定精度を検証するた めの評価実験に関して述べ，5節では評価実験の結果 を受け, 提案手法の有効性について議論する。

\section{2. 関連研究}

本節では, 生体インピーダンス法による内臓脂肪量 の推定に関する先行研究について示し, 実用化に向け た研究の方向性を議論する。一般に, 内臟脂肪量を把 握するための指標として, 臍位断面における内臓脂肪 面積を用いることが有効であることが知られており， 先行研究に打いても内臓脂肪面積を推定する取り組み が行われている. 
Ryoらは，臍から背側へ電流を通電した時の側腹部 のインピーダンスとウエスト周囲長を特徴量として用 いることで, 内臓脂肪面積を推定する手法を提案した [4]．彼らの用いている推定モデルは，式(1)に示す線 形回帰モデルを採用している。

$\widetilde{S} v_{c 1}=a_{0} V_{0} w^{3}+a_{1}$

ここで, $\widetilde{S} v_{c 1}$ は内臓脂肪面積の推定值, $V_{0}$ は計測した インピーダンス，wはウエスト周囲長である。また， $a_{\mathrm{i}}(\mathrm{i}=0,1)$ は回帰係数である.

著者らは, 腹部全域のインピーダンス, 腹部表面の インピーダンスとウエスト周囲長を特徴量として用い ることで，内臓脂肪面積を推定する手法を提案した [5]。この手法では, 計測領域の異なる 2 種類の生体 インピーダンスを用いることにより，皮下脂肪の影響 を低減し, 内臓脂肪面積を推定している。この手法で 提案される推定モデルを式(2)に示す.

$\tilde{S} v_{c 2}=b_{1} w^{2}-b_{2} \frac{1}{Z_{t}}-b_{3} Z_{s} w-b_{4}$

ここで, $\widetilde{S} v_{c 2}$ は内臟脂肪面積の推定值, $Z_{t}$ は腹部全域 のインピーダンス, $Z_{s}$ は腹部表面のインピーダンスで ある. $b_{t}(i=1 \sim 4)$ は回帰係数である。なお，式 $(2) に$ おいて，第一項の $w^{2}$ は腹部断面積を，第二項の $1 / Z_{t}$ は除脂肪面積を，第三項の $Z_{s} w$ は皮下脂肪を表す特徴 量である。すなわち，式(2)が示すように，本手法は 腹部断面積から皮下脂肪面積および除脂肪面積を減ず ることによって内臓脂肪面積を推定している.

これら 2 つ手法はインピーダンスの計測装置が異 なるものの，腹部の断面形状および計測点との関係性 を考慮した推定モデルを構成するという点で共通して いる。これらは，推定に用いる特徴量が理解し易く， 推定モデル自体も透明性が高いという利点がある.

一方, Ryoらの研究グループの片嶋によると, 式 (1)に示す推定モデルに年齢を導入し，さらに性別に よる層別を行うことで, 相関值による評価結果が向上 することが報告されている $[6]$. また, 生体インピー ダンスから除脂肪量や体内総水分量を推定する方法に おいては，性別や年歯に加えて身長や体重などの情報 を推定モデルに導入し，推定精度を向上している[7]$[10]$.

以上の研究事例から，推定モデルの複雑化によっ て, 実用性に足る推定精度を確保するという有用な研 究の方向性が考えられる。ただ, 生体の組成が持つ複 雑性と個別性を考慮して生体のモデルを仮説立て，解 析的に複雑な推定モデルを構築することは高いコスト を要する。よって, 生体の複雑性と個別性を考慮しな
がらも，推定モデルを複雑化する手法が必要となる。

\section{3．計測原理および提案手法}

本節では, 生体インピーダンス法の計測原理を示し た上で, 高精度の推定モデルを構築する手法を提案す る. 本稿で提案する手法では, まず生体の複雑性と個 別性に対応するために, 様々な特徵量を準備する. 次 に，続いてそれらの中から内藏脂肪面積を推定するた めに有効な特徵量を統計的基準により選定する.

\section{1 生体インピーダンス法の計測原理}

本研究では, 著者らが以前に行った研究[11]と同様 に, 腹部全域のインピーダンス, および腹部表面のイ ンピーダンスの 2 種類のインピーダンスを計測する。 腹部全域のインピーダンスは, 腹部全域に通電する が, 電流は主に電気抵抗が小さい除脂肪組織を流れる ため, 腹部の除脂肪組織の量に影響を受ける。また， 腹部表面のインピーダンスは, 腹部表層部に通電する が，腹部表層部は主に皮下脂肪によって構成されてい るため，皮下脂肪量に影響を受ける。以下に，これら 2 種類のインピーダンスの具体的な計測方法について 示す.

はじめに, 腹部全域のインピーダンスの計測方法に ついて述べる，通電用の電極対と計測用の電極対を準 備する，通電用の電極対を両手甲および両足甲に配置 し，計測用の電極対を臍位のウエスト周囲上に 8 組配

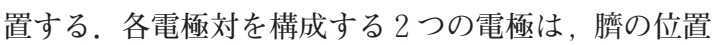
を中心として縦方向に $9 \mathrm{~cm}$ 間隔で配置する。なお， 計測用の 8 組の電極対は, 幅 $11 \mathrm{~cm}$ のベルトに取り付 けてあり，このべルトを臍位の中心に合わせて腹部に 巻くことで, 計測用の電極対を腹部に配置することが 可能である，以上の配置を行った後，両手足甲の電極 対に微弱な電流を通電し, 腹部の電極対にてインピー ダンスを計測する。ここで，8組の電極対で計測され たインピーダンスの平均值を腹部全域インピーダンス $Z_{t}$ と呼ぶ。

次に, 腹部表面のインピーダンスの計測方法につい て述べる。通電打よび計測のための電極対として, 腹 部全体のインピーダンスを計測するために腹部に配置 した 8 組の電極対を利用する． 8 組の電極対を，その 配置箇所によって 4 グループ(臍位の腹側左, 腹側 右，背側左，背側右)に分ける。各グループには $2 つ$ の電極対があり，一方の電極対で通電し，他方の電極 対でインピーダンスを計測する. 得られる 4 グループ 8 箇所のインピーダンスの平均を腹部表面インピーダ ンス $Z_{s}$ と呼び, 腹側の 2 グループ 4 箇所の平均を臍 位腹側の表面インピーダンス $Z_{s f}$, 腹部背面の 2 グ 
ループ 4 箇所の平均を臍位背側の表面インピーダンス $Z_{s b}$ と呼ぶ.

\section{2 計測值データベース}

本稿で活用する計測值データベースについて示す. 被験者は，疾患を抱えていない健常な成人 90 名とし た．被験者の性別ごとの人数，年齢を表 1 に示す.

本研究では, 前節で示した生体インピーダンス法を 用いる 2 種類のインピーダンスの計測に加え，個人の 体格を知るために，図 1 に示す装置を用いて臍位の横 幅 $a$ と縦幅 $b$ を線CTPMRIの計測と同じ条件，す なわち仰臥位にて計測する。最後に，テープメジャー を用いて，立位ウエスト周囲長wを計測する。

また，推定モデルを構築するために真值として用い る内臟脂肪面積の計測を行う。その測定には，一般に 用いられているX線CTと同等の精度で, 被曝の問題が 無いMRIを用いる，使用するMRI装置は，東芝社製の MRI診断装置(VISART EX)である。被験者はMR室内 のベッドに仰臥位となり，スライス厚 $10 \mathrm{~mm}$ の設定で グラジエントエコー法(フィールドエコー法)により臍 位の横断面を撮影する。得られた横断面から，画像処 理ソフトゥェア(SliceOmatic：Tomovision社製）を用 いて内臓脂肪面積を求める。

表 1 被験者の性別ごとの人数と年齢

\begin{tabular}{c|c|c}
\hline & 男性 & 女性 \\
\hline \hline 人数 & 50 [人] & 40 人] \\
\hline 年齢 & $24 \sim 72$ [歳] & $25 \sim 55$ [歳] \\
(平均 \pm 標準偏差) & $(41.9 \pm 11.2)$ & $(39.6 \pm 7.2)$ \\
\hline
\end{tabular}

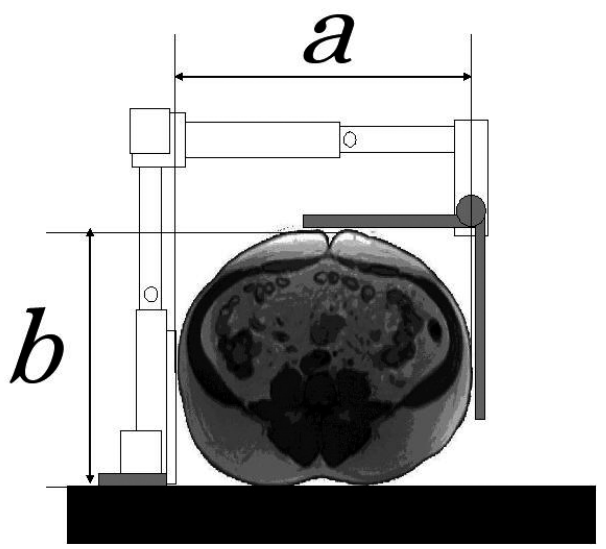

図 1 臍位の形状計測

\section{3 推定モデルの構築手法}

本節では, 生体の複雑性, および個別性を考虑した 推定モデルの構築手法を提案する. 本研究において, 生体の複雑性とは, 生体の構造が内臓脂肪や皮下脂 肪，さらには筋肉や骨格などの多くの組成から成り 立っていることを指し，個別性とは，その体格，打よ び体組成に個体差があることを意味する。内蔵脂肪面 積を精度良く推定するためには, この個体差に対応す る必要がある。本研究では, この課題に対して，2つ の取り組みを行う。まず, 生体情報に含まれる個体差 に対して敏感に反応する特徴量, および個体差の影響 を受けにくい特徴量といった性質の異なる特徴量の準 備を行うことで, 特徴量のバリエーションを確保す る. その後, その特徴量群から前述の個体差に対応す る上で有効な特徵量の選定を行う。

\subsection{1 特徴量のバリエーション確保}

特徵量のバリエーションを確保するにあたって, 試 行錯誤的に特徵量を準備することは非効率である。ま た, 定性的な議論ばかりでは, バリエーションの確保 についての評価が困難である，そこで本研究では，ま ず内臓脂肪量と関係すると想定される特徴量を準備す る。次に，カーディナリティ (濃度)の概念を導入し， 特徴量の性質を定量的に評価する。この指標を用いる ことで, 性質の異なる特徴量を効率的に準備するこ と，および特徵量選択の基準とすることが可能とな る.

本研究に打いて準備した特徴量について述べる。こ こで，3.1節，3.2節にて示した各種計測值を第一次特 徵量, また, 当該計測值に対して次元の拡張や複数の 計測值を組み合わせて演算処理を施したものを第二次 特徵量と呼ぶ。まず, 腹部の形状に関する計測值であ る臍位の横幅 $a$ と縦幅 $b$, 立位ウエス卜周囲長 $w$ を第 一次特徴量として準備した。 また, 腹部断面が円形で あると仮定した場合に，その断面積と比例関係となる 和を第二次特徴量として準備した。

次に, インピーダンス $Z_{t}$ と $Z_{s}$ に関して, $1 / Z_{t}$ は除 脂肪を表し， $Z_{s} \cdot w$ は皮下脂肪を表すことが示されて いる [5]ことから，これらの特徵量を第二次特徴量と して準備した。加えて, 四 2 に示すように腹側と背側 で皮下脂肪の分布が異なることを考慮し，臍位腹側の 表面インピーダンス $Z_{s f}$, 臍位背側の表面インピーダン 又 $Z_{s b}$ を利用して, 前面の皮下脂肪と比例関係になる $Z_{s f}\left(a^{2}+b^{2}\right)^{1 / 2}$, 背面の皮下脂肪と比例関係となる $Z_{s b}\left(a^{2}+b^{2}\right)^{1 / 2}$ 第二次特徴量として準備した。ここ で, $\left(a^{2}+b^{2}\right)^{1 / 2}$ は, 腹部の断面を楕円と仮定した場合 のウエスト周囲長に比例するものである. 


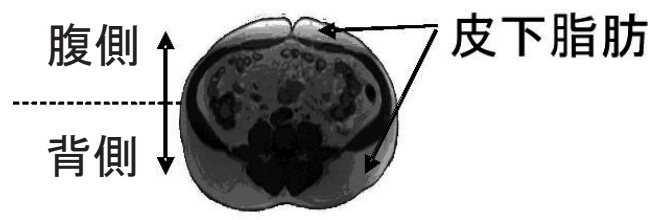

図 2 皮下脂肪の分布

ここで，本研究におけるインピーダンスの計測で は，計測用の電極対をべルトに固定してあるため，各 電極を正確な位置に配置することができる。しかし， 腹部の寸法および断面積に個体差があるため, 個体に よって臍位置に対する電極の相対的な位置が異なる。 そのため, 個体によって電極配置位置付近の脂肪分布 が異なる可能性がある。すなわち, 計測されるイン ピーダンスは, 腹部の寸法や断面積の影響を受けると 考えられる。この影響を表現するため, 腹部の寸法や 断面積を表す特徴量を追加する。腹部の断面積を表す 特徴量として, 横幅 $a$, 縦幅 $b$ を長さの次元から面積 の次元に拡張した $a^{2}, b^{2}$ を第二次特徴量として準備し た。

最後に, 生体インピーダンスから除脂肪量や体内総 水分量を推定する方法 [7]-[10]において, 特徴量とし て用いられている身長 $H$, 体重 $W$, 年歯令 $A$, 性別 $G$ を準 備した。

続いて, カーディナリティにより上記で準備した各 特徵量の性質を定量的に評価する。カーディナリティ とは集合の要素数を表す概念である [12]。例えば，性 別の場合, 要素は「男性」と「女性」であり, カーディナ リティは 2 となる。すなわち，この概念を用いること で，生体情報に含まれる個体差に対する各特徴量の表 現能力を定量化することができる. 本研究では, カ一 ディナリティの取り得る範囲を $[0,1]$ の範囲に正規化 するために, 式(3)に示すように, カーディナリティ を全データで除したNC(Normalized Cardinality) とい う評価指標を定義する。以降, 特徵量 $j$ に対する $N C$ を正規化カーディナリティ $N C_{j}$ と呼ぶ.

$N C_{j}=\frac{C_{j}}{N}$

ここで， $C_{j}$ は特徵量 $j$ に対するカーディナリティであ り， $N$ は全データ数である。一般に，NC が大きい特 徵量ほど, その特徴量が表現する対象の特性を小さな 粒度で定量化し, 逆に $N C$ の小さい特徴量ほど, 特性 を大きな粒度で定量化する。

表 2 に前述で準備した特徴量の $N C$ を示す.
表 2 特徴量と $N C$ の一覧

\begin{tabular}{|c|c|c|}
\hline \multicolumn{2}{|c|}{ 特徵量 } & $N C_{j}$ \\
\hline $1 / Z_{t}$ & 第二次特徵量 & 1.00 \\
\hline$Z_{s} \cdot w$ & 第二次特徵量 & 1.00 \\
\hline$Z_{s f}\left(a^{2}+b^{2}\right)^{1 / 2}$ & 第二次特徴量 & 1.00 \\
\hline$Z_{s b}\left(a^{2}+b^{2}\right)^{1 / 2}$ & 第二次特徵量 & 1.00 \\
\hline$b$ & 腹部の縱幅 & 0.98 \\
\hline$b^{2}$ & 第二次特徴量 & 0.98 \\
\hline$a$ & 腹部の横幅 & 0.80 \\
\hline$a^{2}$ & 第二次特徴量 & 0.80 \\
\hline$w$ & ウエスト周囲長 & 0.72 \\
\hline$w^{2}$ & 第二次特徵量 & 0.72 \\
\hline$W$ & 体重 & 0.63 \\
\hline$A$ & 年齢 & 0.40 \\
\hline$H$ & 身長 & 0.34 \\
\hline$G$ & 性別 & 0.02 \\
\hline
\end{tabular}

\subsection{2 特徵量の選定}

本研究は, 推定モデルの複雑化による精度向上を狙 うものであるが, オッカ厶の㖆象徴されるように本 質的なモデルは単純である。前節で複雑化のために特 徵量のバリエーションの確保を試みた。本節では，そ れらの特徴量から適切なものを選定し, 推定モデルを 形成することを試みる。すなわち，特徴量のバリエー ションの確保は複雑化のプロセスであり, 本節で述べ る選定は単純化のプロセスと位置づけられる。なお， 本稿では推定モデルの透明性を確保するため，二ュー ラルネットワークなどのブラックボックスモデルでは なく，重回帰モデルによる推定手法を採用する。

本研究では, 特徴量の選定のために, 赤池情報量規 準AIC (Akaike Information Criterion)を用いた。AIC は, モデルの単純さと既知のデータへの適合性能を両 立したモデルを選択するための統計的な基準である. 前節で準備した特徵量の全ての組み合わせにおいて重 回帰モデルを作成し, その中から $A I C$ によ有効と 判断される重回帰モデルを選択することで有効な特徴 量を見つける。重回帰モデルの評価を行う場合, $A I C$ は以下の式で表される。

$$
\begin{aligned}
A I C= & N \log \left(2 \pi \hat{\sigma}^{2}\right)+\frac{1}{\hat{\sigma}^{2}} \sum_{i=1}^{N}\left\{y-\left(\gamma_{0}+\gamma_{1} x_{1}+\cdots+\gamma_{m} x_{m}\right)\right\}^{2} \\
& +2(m+2)
\end{aligned}
$$

ここで, $N$ はデータ数, $y$ はモデルの目的変数, $x$ は 説明変数, $m$ は説明変数の数, $\hat{\sigma}$ は推定值の誤差の標 準偏差, $\gamma$ は係数である.

本研究において, 目的変数は内臓脂肪面積の真值で 
あり, 説明変数は, 内臟脂肪面積を推定するために用 いる特徵量を指す。このAICが小さいものは，モデル の単純さとサンプルデータへの適合性を両立した良い モデルと判断される.

しかし, 本研究にて準備した表 2 に示す特徴量は, 第一次特徵量を拡張したものも存在し, 各特徴量間の 直交性が完全に満たされていない，すなわち，多重共 線性による推定精度の低下を引き起こす可能性があ る。そこで，この問題を回避するために，AICにおけ る特徵量の選択過程において, ある第一次特徴量, お よびその第一特徵量から構成される第二次特徵量が同 時に選択されないようにした。例えば， $a, a^{2}$ が同時 に選ばれることはない。

\section{4. 評価実験}

前節において, $N C$ を用いて特徴量のバリエーショ ンを確保した後, 有効な特徴量の選択を行うことに よって，推定モデルを構築する手法を提案した，本節 では, 特徴量を準備するための評価指標として定義し た $N C$ を活用することの有効性を検証するために, 従 来提案されている推定モデルを準備し, それと提案手 法に基づく推定モデルの推定精度の比較評価を行う。

\section{1 推定モデル}

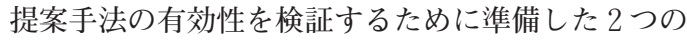
推定モデルについての詳細を示す。

従来モデル

2 節で示した, 著者らが以前の研究にて提案した式 (2)に示す推定モデルを比較対象として準備した。こ の推定モデルを従来モデルと呼ぶ.

提案モデル

3.2.節に示したデータ母集団を用いて, 表 2 に示す 全特徴量から提案手法により, 特徴量を選定し構築し た推定モデルを提案モデルと呼ぶ．提案モデルを式 (5)に示す.

$$
\begin{array}{r}
\widetilde{S} v_{p}=\alpha_{1} a^{2}+\alpha_{2} b+\alpha_{3} Z_{s b} \sqrt{a^{2}+b^{2}} \\
+\alpha_{4} 1 / Z_{t}+\alpha_{5} A+\alpha_{6} G+\alpha_{7}
\end{array}
$$

ここで， $\widetilde{S} v_{p}$ は内臓脂肪面積の推定值， $\alpha_{i}(i=1 \sim 7)$ は 回帰係数である.

従来モデルに打いて, 腹部の形状を表現する特徴量 としてウエスト周囲長 $w$ が用いられていたのに対し， 提案モデルでは, 腹部の横幅 $a$ および縦幅 $b$ やその 変数変換した特徵量を選定している。提案モデルに組
み込まれた特徵量の $N C$ に注目すると, 従来モデルに おけるwよりも大きい。 また, 従来モデルには用いて いなかった年齢 $A$ や性別 $G$ を選定している。これら の特徵量は他の特徴量と比べ $N C$ が小さく, 提案モデ ルは $N C$ の大きい特徴量と $N C$ の小さい特徴量の両方 を含んでいる。

\section{2 評価指標}

本評価実験では, 各推定モデルの推定精度を評価す るための指標として, 次に示す相関係数, 誤差平均お よび䛊差標準偏差を用いる，以下に，これらの評価指 標の詳細について示す.

\section{相関係数}

任意の推定モデルによる内臓脂肪面積の推定値と MRIより得られる真值の相関をピアソンの積率相関係 数により算出することで, 未知の個体に対する表現性 能, すなわち内臟脂肪面積が小さい個体から大きい個 体まで, 高い推定精度を確保できるか否かを評価す る.

\section{誤差平均值}

任意の推定モデルによる推定值とMRIより得られる 真值との誤差の平均值により, 未知の個体に対する推 定精度の高さを評価する。

\section{䛊差標準偏差}

任意の推定モデルによる推定値とMRIより得られる 真值との誤差の標準偏差により，未知の個体に対する 推定精度の安定性を評価する。

\section{3 実験方法}

Leave-One-Out交差検証法を用いて各推定モデル の比較評価を実施する．手順の詳細を以下に示す。

(1) 3.2 節に示したデータ母集団から 1 つの個体を 取り出し, 残りのデータ群で各推定モデルの回 帰係数の学習を行う。

(2) (1)で取り出した個体を用いて, 各推定モデルか ら推定值を算出する。

(3) (1)，(2)を全ての個体において実施する.

(4) 上記において算出された推定值とMRIを用いて 計測される真值との相関係数, および誤差平 均, 誤差標準偏差の算出を行う。

\section{4 評価結果}

従来モデルと提案モデルによる推定值と真值の相関 係数, 誤差平均, 誤差標準偏差の結果を表 3 に示す。 
表 3 各推定モデルに打ける評価指標の結果

\begin{tabular}{l|r|r|r}
\hline & 相関係数 & $\begin{array}{r}\text { 誤差平均 } \\
{\left[\mathrm{cm}^{2}\right]}\end{array}$ & $\begin{array}{r}\text { 誤差標淮偏差 } \\
{\left[\mathrm{cm}^{2}\right]}\end{array}$ \\
\hline \hline 従来モデル & 0.64 & 23.73 & 29.97 \\
\hline 提案モデル & 0.85 & 16.51 & 20.47 \\
\hline
\end{tabular}

表 3 より, 表現性能を表す相関係数において, 提案乇 デルが従来モデルに比べ高いことがわかる．また，誤 差平均, 誤差標準偏差に扔いて, 提案モデルが従来モ デルに比べ小さい值となっている.

\section{5. 考察}

前節の評価結果で示したように，提案モデルに基づ く内蔵脂肪面積の推定性能は大幅に向上した。本節で は, 多変量推定モデルに扔ける重要課題である変数選 択に着目し，提案手法の位置づけを明確にしながら考 察を進める。

はじめに, 既存の有効特徴量の選択手法について議 論する。まず，各特徴量間の直交性を評価する方法 [13]がある。この手法は, 各特徴量間の直交性を確保 すべく特徵量を選択することで, 多重共線性による推 定精度の低下を回避する。直交性を評価する指標とし ては, 各特徵量間の相関係数や, 各特徵量間で単回帰 式を構築した時の最小二乗誤差が用いられている.

また, その他の指標として, 各特徴量間の共分散行 列の最小固有值 $\lambda_{2}$ が用いられる。 $\lambda_{2}$ は，2つの特徴 量を $x_{1}, x_{2}$ とした場合, 以下の式で表される.

$$
\begin{aligned}
& 2 \lambda_{2}=\operatorname{var}\left(x_{1}\right)+\operatorname{var}\left(x_{2}\right)- \\
& \quad \sqrt{\left(\operatorname{var}\left(x_{1}\right)+\operatorname{var}\left(x_{2}\right)\right)^{2}-4 \operatorname{var}\left(x_{1}\right) \operatorname{var}\left(x_{2}\right)\left(1-\rho\left(x_{1}, x_{2}\right)^{2}\right)}
\end{aligned}
$$

ここで, $\operatorname{var}$ は分散, $\rho$ は相関係数である. $\lambda_{2}$ の值は, 2 つの特徵量が直交する場合 0 となる。逆に 2 つの特 徵量の直交性が低くなると, $\lambda_{2}$ は大きくなる.

次に, 複数の特徴量の組み合わせにおける表現力を 評価する方法[14]-[16]がある。Jolliffeは，用意した 全特徴量で主成分分析を行い, 寄与率の高い主成分に 対する影響が強い特徵量を採用し, または寄与率の低 い主成分に対して影響の強い特徴量を削除することに より，有効特徴量を選択する手法 [14][15]を提案し た.

また, McCabeは特徴量の全ての組み合わせにおけ る共分散行列を作成し，その共分散行列の固有值の和 や積が最小になる組み合わせを抽出することで有効特 徴量を選択する手法[16]を提案した. JolliffeやMcCabe によって提案されたこれらの手法によって, サンプル データが持つ情報に対する表現力を確保する特徵量の
組み合わせを選択することができる．

上記で述べた既存の特徴選択手法は, 目的に応じて 複数の特徵量の組み合わせを評価し, 直交性の確保や 表現能力の維持を実現する上で有効な手法である。一 方, 提案手法で用いている $N C$ は, 個々の特徵量の持 つ濃度を評価する指標である。以下では, 実験結果を 踏まえて, $N C$ を用いて特徴量を評価することの有効 性を考察する。

推定モデルに組み込まれている特徵量の $N C$ と推定 モデルの精度の関係を明らかにするために, 式(5)に 組み込まれている特徴量のうち, 内臟脂肪計測に重要 だと思われる特徴量のみから構成される推定モデルを 準備する。結果として, この推定モデルは $N C$ の大き い特徴量から構成されることとなり， $N C_{l}$ モデルと呼 ぶ. 本推定モデルを提案モデルと比較し, $N C$ の大小 が推定モデルに対して与える影響を考察する。 $N C_{l}$ モ デルを式(7)に示す.

$$
\begin{gathered}
\widetilde{S} v_{l}=\beta_{1} a^{2}+\beta_{2} b+\beta_{3} Z_{s b} \sqrt{a^{2}+b^{2}} \\
+\beta_{4} 1 / Z_{t}+\beta_{5}
\end{gathered}
$$

ここで, $\widetilde{S} v_{l}$ は内臟脂肪面積の推定值, $\beta_{i}(i=1 \sim 5)$ は 回帰係数である.

次に, $N C$ の偏りの違いによる推定精度の差異を確 認するために, 個体差に対する推定精度のばらつきを 評価することを考える。ここで，個体差を定量的に示 す指標について考察すると, 複数の観点があることに 気づく，例えば，健康診断にも用いられているBMI， ウエスト周囲長などがある。しかし，これらの個々の 指標により個体差を完全に表現することはできない. このように個体差を定義し, それを表現する尺度を単 純に構成することは困難である。そこで, 本研究では 個体差の代替尺度としてマハラノビス距離 [17] 用い ることとする. マハラノビス距離とは複数の特徴量を 用いて， ある集団の標準的特性とある個体の特性との 類似性を 1 つの值として定量化することができるとい う特長を持つ。

以下に，上記のマハラノビス距離を尺度とした場合 の推定精度のばらつきに関する評価手順を示す.

(1) 本稿では, 実験に打いて, Leave-One-Out 交 差検証法にて用いた個人とその個人を除く母集 団との乘離度合いをマハラノビス距離により算 出する。このマハラノビス距離が小さい, すな わち母集団の特性に近しい個人は, 標準的な特 性を持つといえる。

(2) (1)で算出した個々人に対するマハラノビス距離 の中央值を基準として, マハラノビス距離が中 央值よりも小さな群を標準個体群, 大きい群を 


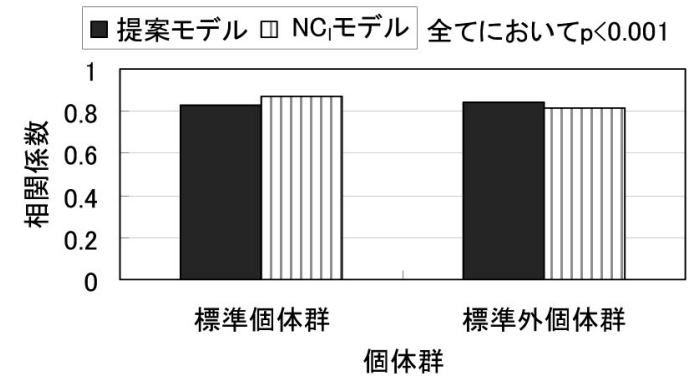

図 3 各推定モデルにおける推定值と真值の相関係数

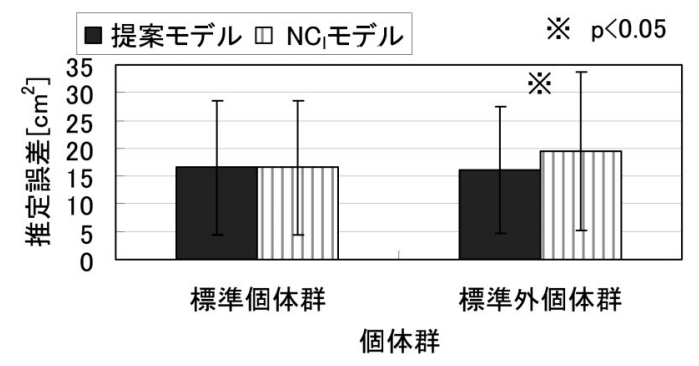

図 4 各推定モデルの推定䛊差の平均と標準偏差

標準外個体群と定義する.

(3) 標準個体群と標準外個体群の各々の群につい て, MRIの真值と推定モデル(提案モデル, ま たは $N C_{l}$ モデル)による推定值の相関係数, 䛊 差平均, 誤差標準偏差を算出する.

以上の手順により得られた 2 種の推定モデルに関す る結果を図 3 , 図 4 に示す。

四 3 から, 各推定モデルによる推定值と真值の相関 係数は同程度であることがわかる. すなわち, 従来モ デルと比較し, $N C_{l}$ モデルも推定精度が飛躍的に向上 しているものと考えられる。

ここで, 図 4 に示す標準外個体群に対する提案モデ ルの推定䛊差の平均は, $N C_{l}$ モデルと比較し, $3.0 \mathrm{~cm}^{2}$ 小さくなっていた $(\mathrm{p}<0.05)$ 。すなわち，NCの大きな 特徴量と小さな特徵量を組み合わせることにより, 母 集団に対する個体差が大きな個体において推定が精度 良く行えている。

\section{6. おわりに}

本研究では, 生体インピーダンスなどの生体情報を 用いた内藏脂肪面積の推定手法を構築した。本稿では 特に, 有効な特徵量の選定および推定モデルの獲得に ついての議論を中心に行った。ここでの課題は, 生体 の個体差への対応である。これを解決するために, ま ず, 特徴量のバリエーションの確保, すなわち性質の
異なる様々な特徵量を準備した。 ここで, 特徵量のバ リエーションを確保するために, カーディナリティを 用いて, 特徴量が持つ性質の定量評価を行った。カー ディナリティとは集合論によって与えられた概念であ り, 集合の要素数を表す. 本稿では, このカーディナ リティをサンプル数で割ることで正規化した正規化 カーディナリティという指標を活用し, 準備した特徴 量の評価を行った。さらに, 準備した特徴量の中か ら, 内臟脂肪面積を推定するために最適な特徵量を選 定した。ここでは, モデルの評価指標として一般的に 用いられている $A I C$ を活用した。 上記の手法にて選 定した特徵量を用いて内臓脂肪面積の推定モデルを構 築し, 評価実験を行った結果, その有効性を確認し た。

以上より, 本稿にて提案した手法は, 従来研究と比 較し, 推定モデルは多少複雑となったが, 実用性を考 慮すると有益な方法論であると言えよう。

今後, 本研究の成果が, メタボリックシンドローム の診断や治療に関する医療における発展の一助とな り, 国民の疾病予防・健康増進に貢献できれば幸いで ある。

\section{参 考 文 献}

[1] Examination Committee of Criteria for 'Obesit Disease' in Japan, Japan Society for the Study of Obesity, "New Criteria for 'obesity disease' in Japan," Cric J 66 (11), pp987-992, 2002.

[ 2 ] Tatsuya Gomi, et al, "Measurement of Visceral Fat/ subcutaneous Fat Ratio by 0.3 Tesla MRI," Radiation Medicine, 23 (8), pp584-587, 2005.

[ 3 ] Miyawaki T, et al, "Metabolic syndrome in Japanese diagnosed with visceral fat measurement by computed tomography," Proc Japan Acad 81, pp.471-479, 2005.

[4] Ryo.M, et al, "A New Simple Method for the Measurement of Visceral Fat Accumulation by Bioelectrical Impedance," Diabetes Care, 28, pp451-453, 2005.

［5］志賀利一, “インピーダンス法による新規の内臟脂肪 測定法,”最新医学, 3 月増刊号, pp615-623, 2006

［6］片嶋充弘, 他, “腹部生体インピーダンス法を用いた 内臟脂肪測定器の開発一測定原理の検証-, ”健康医 学, 19 (3), pp391-396, 2004.

[ 7 ] Houtkooper LB et al, "Why bioelectrical impedance analysis should be used for estimating adiposity," Am J Clin Nutr 64, pp436-448, 1996

[8] van Marken Lichtenbelt WD,et al, "Validation of bioelectrical-impedance measurements as a method to estimate body-water compartments," Am J Clin Nutr, 60, pp159-166, 1994.

[ 9 ] Deurenberg P,et al, "Assessment of body composition by bioelectrical impedance in a population aged $>$ 60 y," Am J Clin Nutr,51, pp3-6,1990. 
[10] Rising R, et al, "Body composition in Pima Indians: validation of bioelectrical resistance," Am J Clin Nutr53, pp594-598,1991.

[11] T.Shiga, et al, "A Simple Measurement Method of Visceral Fat Accumulation by Bioelectrical Impedance Analysis," IFMBE Proceedings 17, pp. 687-690, 2007.

[12］宮本敏雄, “基礎数学ハンドブック,”森北出版, 1964 .

[13] Sankar K. Pal, et al, "Pattern Recognition Algorithms for Data Mining, "Chapman \& Hall/CRC, pp. 64-68, 2004.

[14] Jolliffe, I. T. , "Discarding Variables in a principal component analysis I. Artificial data," Appl. Statist., 21, pp.160-173, 1972.

[15] Jolliffe, I. T. , "Discarding Variables in a principal component analysis II. Real data," Appl. Statist., 22, pp.21-31, 1973.

[16] McCabe, G. P. , "Principal Variables," Technometrics, 26, pp.137-144, 1984.

[17] P.C. Mahalanobis, "On the generalised distance in statistics," Proceedings of the National Institute of Science of India 12, 49-55, 1936.

（2007年 6 月15日 受付）

(2007年 8 月24日 採録)

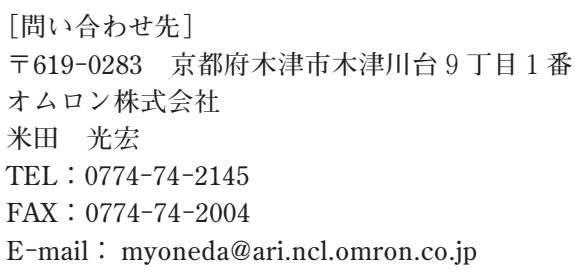

E-mail : myoneda@ari.ncl.omron.co.jp 


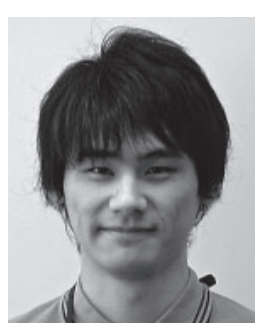

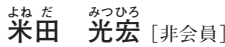

2005 年同志社大大学院工学研究科 機械工学専攻修了. 同年オムロン株式 会社入社. 現在に至る。音・振動を用 いた製品検査に関する研究開発に従 事.

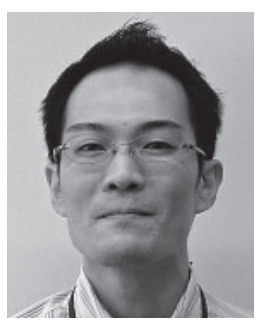

\section{土屋直樹 [非会員]}

2001年神戸大学大学院自然科学研 究科電気電子工学専攻修了。同年, 才 ムロンソフトウェア株式会社入社. 音 声の特徴抽出, 認証技術に関する研究 開発に従事。2005年オムロン株式会 社に転籍. 現在に至る。音・振動を用 いた製品検査に関する研究開発に従 事.

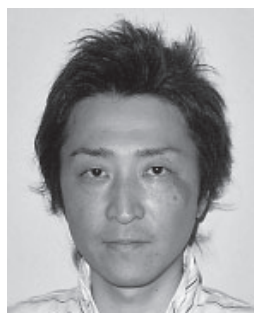

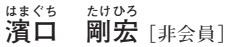

1996 年金沢工業大学電子工学科 卒. 同年オムロン松阪株式会社に入 社. 2002 年オムロンライフサイエン ス研究所(現オムロンヘルスケア株式 会社)に転籍. 現在に至る。生体イン ピーダンス計測の研究, 生体インピー ダンス計測を応用した内臓脂肪計に関 する設計・開発に従事.

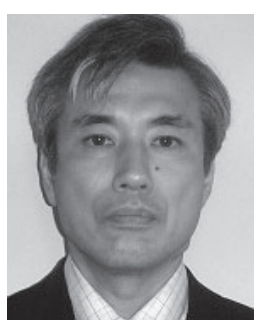

\section{志賀 脷一加 [非会員 $]$}

1986年北海道大学大学院工学研究 科生体工学専攻修士課程終了。同年, 株式会社立石ライフサイエンス研究所 (現オムロンヘルスケア株式会社)入 社. 現在に至る。1998年北海道大学 大学院工学研究科生体工学専攻博士課 程修了, 博士(工学)。生体計測基礎技 術研究開発に従事.

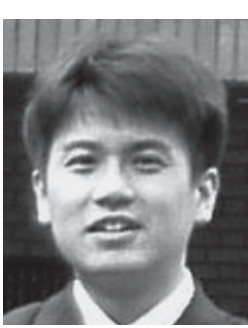

\section{态㟝 博 [非会員]}

2003 年岡山大学大学院自然科学研 究科修了。同年才ムロン株式会社入 社. 現在に至る。熟練者の知恵やノウ ハウをシステム化する研究に従事.

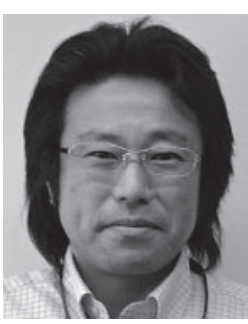

\section{中嶋 宏 [正会員]}

1985年神戸大学工学部システム工 学科卒業. 同年立石電気株式会社 (現 オムロン株式会社) 入社. 現在に至 る。ソフトコンピューティング, 人間 一機械協調システムの研究に従事. 博 士(工学). International Journal of Intelligent Computing in Medical Sciences and Image Processing Associate Editor. 2007年IFSA Industrial Application Award受賞.

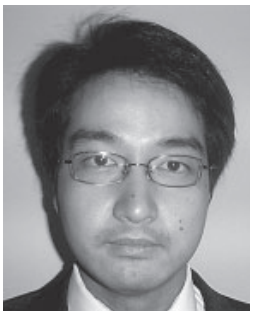

\section{敝 芷次郎 [非会員]}

1997年新潟大学大学院自然科学研 究科修了。同年, 株式会社オムロンラ イフサイエンス研究所(現オムロンへ ルスケア株式会社) 入社. 現在に至 る. 血圧計の開発, 健康アドバイスシ ステムの開発, インピーダンス計測技 術開発に従事. 電子情報通信学会会 員. 


\section{Development of Visceral Fat Estimation Model Based on Bioelectrical Impedance Analysis Method}

by

\section{Mitsuhiro YONEDA, Hiroshi TASAKI, Naoki TSUCHIYA, Hiroshi NAKAJIMA, Takehiro HAMAGUCHI, Shojiro OKU and Toshikazu SHIGA}

Abstract :

The method of bioelectrical impedance-based visceral fat estimation is in advance of other methods such as CT or MRI viewed from points of cost and safety. However, the method requires complex signal analysis and modeling to realize its high estimation accuracy factoring in individuality. In response to the requirement, the assurance of the feature attributes' variation and the selection of them to develop the estimation model have been proposed in this paper. The assurance of the feature attributes' variation is realized by employing the idea of cardinality as a quantitative evaluation index. The selection of the feature attributes is realized by employing the Akaike information criterion. The experiments were conducted to evaluate the proposed method. The results prove that the estimation model developed by the proposed method provide high estimation accuracy and stability.

Keywords : Feature Selection, Cardinality, Visceral Fat, Subcutaneous Fat, Bioelectrical Impedance Analysis.

Contact Address : Mitsuhiro YONEDA

OMRON Corporation

9-1 Kizugawadai, Kizugawa City, Kyoto, 619-0283 JAPAN

TEL : 0774-74-2145

FAX : 0774-74-2004

E-mail : myoneda@ari.ncl.omron.co.jp 